\title{
Reducing perceptions of overqualification and its impact on job satisfaction: The dual roles of interpersonal relationships at work
}

\begin{abstract}
A sizeable portion of the working population perceives that they are overqualified for their jobs. This is problematic given that research consistently shows that such beliefs translate into lower levels of job satisfaction. Hence it behoves human resource management scholars to identify factors that influence perceptions of overqualification, and also moderators that may reduce the negative effect of perceived overqualification on job satisfaction. In this study, we present a moderated path model that posits that the quality of the relationships that employees hold with their leader and with their team are not only antecedents of perceived overqualification, but they also are hypothesised to weaken the negative relationship between perceived overqualification and job satisfaction. Survey data that was gathered from two organisations in the Netherlands $(\mathrm{n}=183)$ supported the model. Implications for theory and practice in human resource management are discussed.
\end{abstract}




\section{Reducing perceptions of overqualification and its impact on job satisfaction: The dual roles of interpersonal relationships at work}

One of the central issues facing human resource management (HRM) practitioners is ensuring that employees possess and deploy skills to carry out their jobs successfully (Grugulis, 2003). While HRM research has primarily focused on managing under-skilled workers (e.g., Edwards, Sengupta and Tsai, 2009), more recently, attention has been directed toward managing those who are overqualified for their jobs (Erdogan, Bauer, Peiro and Truxillo, 2011a). This is because a number of conditions, including rising education levels, the global mobility of jobs, and the recent economic crisis have led to a situation in which an increasing number of employees possess more skills and education than what is required for their jobs (Quintini, 2011; Pouliakas, 2013). For instance, research suggests that as many as one in three workers are overqualified in countries such as the United Kingdom, the United States, Canada, and Germany (Groot and Maassen van den Brink, 2000; Quintini, 2011), and the number of overqualified employees is likely to increase in the future (Vaisey, 2006). Overqualification is therefore of central interest to scholars, policy makers, and HRM practitioners.

HRM research has produced compelling evidence that perceptions of overqualification, that is, the extent to which employees are aware of the mismatch between their qualifications and job requirements, has negative consequences for overqualified employees and the organisations that employ them (e.g., Feldman, Leana and Bolino, 2002; Erdogan and Bauer, 2009). Indeed, a robust finding is that employees who perceive that they are overqualified have poor job

satisfaction because they believe that they are deprived of a better job (Crosby, 1976; Feldman $e t$ al., 2002). This is problematic given the association between job satisfaction and a host of 
important individual and organisational outcomes (e.g., Judge, Bono, Thoresen and Patton, 2001; Faragher, Cass and Cooper, 2005). In order to minimise the occurrence and negative consequences of perceived overqualification, HRM scholars must respond to two pressing questions: (1) what factors influence the extent to which employees perceive that they are overqualified for their jobs?; and (2) what factors minimise dissatisfaction due to overqualification?

Theoretical models have shed some light on the first question (Feldman, 1996; McKeeRyan and Harvey, 2011). Indeed, factors such as the economic environment, employees' career history, and employees' traits and work preferences likely influence the extent to which employees feel overqualified for their jobs (see McKee-Ryan and Harvey, 2011, for a review). In the present paper we argue that factors located within an employee's work environment may also be associated with perceived overqualification. This is because proximal factors in the work environment play a dominant role in influencing employee attitudes (Lewin, 1943).

To respond to the second question, it is necessary to explore moderators of the relationship between perceived overqualification and job satisfaction. Examining moderating factors is important, not only because it enhances overqualification theory by identifying conditions under which the relationship between overqualification and job satisfaction is tempered (Whetten, 1989; Colquitt and Zapata-Phelan, 2007), but it also has practical significance. This is because HRM professionals seemingly face a dilemma with regards to engaging and retaining overqualified workers. Although they recognise that many overqualified candidates are likely to perform well in their jobs, HRM professionals are oftentimes fearful of hiring overqualified workers because they believe that they will be less satisfied at work, and may quit if they find an alternative job that is commensurate with their qualifications (e.g., 
Green, 2013; Sullivan, 2014). Hence, identifying factors that reduce the negative relationship between perceptions of overqualification and job satisfaction will help to resolve this dilemma.

The present study was designed to respond to these two questions through an examination of the dual (i.e. independent and moderating) roles of interpersonal relationships at work (see Figure 1) in the context of overqualification. Specifically, we focus on employees' perceptions of the quality of the relationships that they have with their manager, or leadermember exchange (Graen and Uhl-Bien, 1995) and with their team, as indicated by employees' perceptions of team cohesiveness (Schermerhorn, Hunt and Osborn, 2002) as antecedents of perceived overqualification, as well as moderators of the relationship between perceived overqualification and job satisfaction.

Insert Figure 1 about here

\section{Interpersonal Relationships at Work as Antecedents of Perceived Overqualification}

Although researchers in the fields of education and economics suggest that employees are overqualified when their educational qualifications exceed the mean or modal level of qualification held by their occupational group (Pouliakas, 2013), researchers in HRM tend to take a broader view of overqualification. They suggest that it occurs when employees perceive that they have skills, knowledge, abilities, qualifications and/or experience that exceed the requirements of the job, or are not used on the job (Erdogan, Bauer, Peiro and Truxillo, 2011b). We focus on perceptions of overqualification because they take into account more than educational qualifications, they reflect the experience of employees (Zalesny and Ford, 1990; 
Maynard, Joseph and Maynard, 2006) and they are more likely to be related to important job attitudes such as job satisfaction (Erdogan et al., 2011b).

Theoretical models have identified a number of important determinants of overqualification. Most research in this area has focused on either macro-level or demographic factors that tend not to be within an organization's control (i.e. economic conditions within particular industries; employees' race) (e.g., McKee-Ryan and Harvey, 2011). We add to this body of literature by looking inside the organisation for factors that may lessen employees' perceptions of overqualification by examining the quality of their interpersonal relationships with their leader and with their team.

Employees who forge high quality interpersonal relationships at work are likely to report lower perceptions of overqualification because they feel that their knowledge, skills and abilities are utilised at work. For instance, followers of high quality leader-member exchange relationships enjoy more open and honest communication, greater access to resources, and are provided with more challenging job assignments. Their leaders also make them feel more valuable, as they recognise their potential and understand their problems and needs (Graen and Uhl-Bien, 1995). Lower quality relationships, on the other hand, tend to put followers at a relative disadvantage in terms of job benefits and career progression (Vecchio, 1997), as followers receive less information and recognition from their leader (e.g., Gerstner and Day, 1997) and therefore feel less valued by their leader. Unlike those in lower quality relationships, employees who forge high quality leader-member exchange relationships feel more empowered (Aryee and Zhen Xiong, 2006) and they believe that their work is more meaningful (Tummers and Knies, 2013). Therefore, we hypothesise:

H1: Leader-member exchange is negatively related to perceived overqualification. 
Employees who belong to cohesive teams may also feel more utilised at work, and therefore have lower perceptions of overqualification. This is because members of cohesive groups often go beyond their job description to benefit the group due to their enhanced identification and commitment to the team's goals (Hausknecht, Trevor and Howard, 2009; Thatcher and Patel, 2011). Employees who work in cohesive teams interact closely and frequently with each other, which results in a convergence in team members' perceptions regarding the relative strength of individual group members and the group's overall goals (Cartwright, 1968). Members of cohesive teams may feel more valued at work because they get along well with those in their team, and team members defend and assist each other when needed; those who belong to less cohesive teams, on the other hand, lack support and may feel undervalued. Consequently, members of cohesive teams engage in more cooperative behaviours (Van Dyne, Cummings and Parks, 1995; Kidwell, Mossholder and Bennett, 1997), which may prompt them to feel more utilised, even when their knowledge, skills and abilities are not formally required in their job. Hence, we hypothesise:

H2: Team cohesiveness is negatively related to perceived overqualification.

\section{Perceptions of Overqualification and Job Satisfaction}

Previous research has illustrated the negative effects of overqualification for organisations and overqualified individuals. For instance, research has demonstrated that overqualified employees report poorer health outcomes (Johnson and Johnson, 1997), higher intentions to turnover (Maynard et al., 2006; Erdogan and Bauer, 2009), and more negative job attitudes, including disengagement and job dissatisfaction, compared to their adequately qualified counterparts (e.g., Lee, 2005; Kraimer, Shaffer and Bolino, 2009). In the present study, we focus on the relationship between perceived overqualification and job satisfaction, whereby 
job satisfaction is defined as a positive or pleasurable emotional state resulting from the appraisal of one's job (Locke, 1976).

Relative deprivation theory explains the negative relationship between overqualification and job satisfaction; it maintains that people feel dissatisfied with an outcome, including their jobs, when there is a discrepancy between the outcome they want and the outcome they receive; when past experience has led them to expect more than what they currently have; and when they feel that they are entitled to more (Crosby, 1976). Overqualified employees expect to hold jobs in which they are able to fully use their abilities and talents, and given their education and/or work experience, feel that they deserve better jobs (Erdogan and Bauer, 2009). The greater the relative deprivation, the greater the sense of frustration, resulting in increased negative job attitudes, such as job dissatisfaction (Crosby, 1976; Feldman et al., 2002). Hence, we hypothesise:

H3: Perceived overqualification is negatively related to job satisfaction.

\section{The Moderating Role of Interpersonal Relationships on the Link Between Perceived Overqualification and Job Satisfaction}

Despite the evidence that overqualified employees have poorer job attitudes, there may be conditions that mitigate its negative effect (Erdogan et al., 2011b). Since overqualified employees feel deprived of what they deserve, it follows that the provision of alternative resources may compensate for feelings of relative deprivation, thereby weakening the negative relationship between overqualification and job satisfaction.

Important resources that employees can draw from are derived from the interpersonal relationships they hold at work. This is because, according to social exchange theory, parties in 
interpersonal relationships engage in economic and social exchanges. Economic exchanges provide tangible resources that are typically short-term and financially-oriented (Shore, Tetrick, Lynch and Barksdale, 2006), such as money, information, or services. Social exchanges involve the exchange of both tangible and intangible resources that are directed at fulfilling employees' needs for esteem, approval and care, and may include support, friendship and respect (Armeli, Eisenberger, Fasolo and Lynch, 1998; Shore, Bommer, Rao and Seo, 2009). In what follows, we develop theoretical arguments that interpersonal relationship partners provide employees with tangible and intangible resources that may weaken the relationship between perceptions of overqualification and job satisfaction.

\section{The Moderating Role of Leadership}

Overqualified employees with high quality relationships with their leader may believe that their leader provides them with tangible resources. These tangible resources may cause overqualified employees to believe that they are relatively less deprived from what they deserve, thereby reducing the negative relationship between overqualification and job satisfaction. For instance, overqualified employees' leaders may position them for future promotion opportunities so that they can move out of their overqualified job, leaving them more satisfied with their work. Indeed, Seibert, Sparrow and Liden (2003) found that employees who perceive that they have high quality leader-member exchange relationships are more integrated into their leader's network, which may instil in them confidence that their leader will provide them with challenging assignments and growth opportunities in the future. The provision of challenging assignments or other growth opportunities does not change the actual positions that overqualified employees hold in terms of salary level, for instance, yet they do prepare overqualified 
employees to take the next step on their career ladder toward positions in which they feel adequately qualified. Hence, overqualified employees with high quality leader-member exchange relationships may believe that career progress is in store for them, thereby reducing feelings of relative deprivation, and increase levels of job satisfaction.

Alongside tangible resources, high quality leader-member exchange relationships may also provide intangible resources. In high quality leader-member exchange relationships, leaders provide followers with socio-emotional support, such as showing concern or celebrating success, which may reduce the feeling that they are deprived of something that they deserve, making them more satisfied with their jobs. Support for this is found in a study by Ritz, Shantz, Alfes and Arshoff (2012); the authors demonstrated that employees with a negative self-view had higher commitment to change when they also had high quality leader-member exchange relationships. Hence, high quality leader-member exchange relationships may counterbalance the negative effect of overqualification because they minimise the felt relative deprivation that coincides with perceptions of overqualification. Hence, we hypothesise:

H4: Leader-member exchange moderates the negative relationship between perceived overqualification and job satisfaction, such that the relationship will be weaker when leadermember exchange is high.

\section{The Moderating Role of Team Cohesiveness}

In terms of tangible support, team members provide information-related task support, such as advice on how to solve a work-related problem and behavioural task support, such as assistance during task completion (Fenlason and Beehr, 1994). Both types of activities may contribute to weakening the negative effect of overqualification on job satisfaction. For instance, 
task-related support may trigger reciprocal support from others, which increases team members' satisfaction with their jobs. Likewise, behavioural support may cause overqualified employees to be more satisfied with their jobs, as they share information with one another, thereby learning new job roles (Hüffmeier and Hertel, 2011). Since overqualified employees may perceive that they are entitled to more than what they have in their current job roles, these forms of tangible support may counterbalance their feelings of relative deprivation, and therefore increase their levels of job satisfaction.

With regards to intangible resources, cohesive teams provide emotion-related support, such as encouragement and recognition (Carson, Tesluk and Marrone, 2007). Moreover, they promote a sense of purpose, and they make the work situation more enjoyable (Lim, 1996). A cohesive team may stabilise or increase overqualified employees' self-perceptions, which are undercut by their overqualified status. Their sense of relative deprivation may therefore decrease leading to higher satisfaction, given that they have developed emotional bonds with their team members. In a similar way, support from overqualified employees' team members may increase their feelings of belonging, as the success of the team may inform personal self-esteem (e.g., Van Dick, Tissington and Hertel, 2009), therefore leaving them relatively more satisfied with their jobs. Hence, we hypothesise:

H5: Team cohesiveness moderates the negative relationship between perceived overqualification and job satisfaction, such that the relationship will be weaker when team cohesiveness is high.

\section{Methods}

The data were collected from employees who worked at two organisations in different industries located in the Netherlands. A series of t-tests showed that employees did not 
significantly differ along perceptions of overqualification, leader-member exchange, or team cohesiveness between the two organisations.

\section{Company A}

Company A is a multinational fast-moving consumer goods company. A total of 126 employees were sent an e-mail with a link to an online questionnaire. The e-mail explained the purpose of the study and guaranteed participant anonymity and confidentiality. After ten days, participants were sent a reminder to complete the survey. From the sample, 48 questionnaires were returned, resulting in a response rate of $38.09 \%$. The sample comprised $42.6 \%$ women, the average age was 36.57 years ( $\mathrm{SD}=9.7), 79.2 \%$ of the respondents were employed full-time, and the majority of participants held a permanent contract (85.1\%). Participants held administrative, technical support, and sales roles.

\section{Company B}

Company B is an employment agency, and the data were collected following the same procedure as Company A. The sample comprised 346 employees. A total of 135 employees completed the questionnaire, resulting in a response rate of $39.02 \%$. The sample comprised $70.9 \%$ women, the average age was 30.95 years $(\mathrm{SD}=7.7), 57.6 \%$ of the respondents were employed full-time, and $63.9 \%$ of the participants held a permanent contract. The majority of the participants carried out marketing or sales tasks with responsibilities for the acquisition and relationship management of client portfolios. The participants also held administrative or technical support roles. 


\section{Measures}

The study was conducted in Dutch-speaking companies. Hence all of the measures were translated into Dutch using a back-translation procedure (Brislin, Lonner and Thorndike, 1973). All scales were rated on a seven-point Likert-type scale, ranging from (1) strongly disagree to (7) strongly agree.

Perceptions of overqualification was measured using the 9-item scale of perceived overqualification (SPOQ) developed by Maynard et al. (2006). An example item is: 'My job requires less education than I have.' Cronbach's alpha was .88. Given the translation of the measure, the structure of this scale was confirmed via confirmatory factor analysis (Hair, Black, Babin and Anderson, 2009). The results supported the structure and construct validity of the Dutch perceived overqualification scale. The translated measure, along with the results of these analyses, can be obtained from the first author.

Job satisfaction was measured with a 3-item scale used by Takeuchi, Chen and Lepak (2009). An example item is: 'All in all, I am satisfied with my job.' Cronbach's alpha was .91.

Leader-member exchange was measured by Graen and Uhl-Bien's (1995) 7-item leadermember exchange scale. Employee ratings of leader-member exchange were used in the present study because our theorising focuses on how employees perceive the quality of the leadermember relationship and the support they receive from their supervisor. An example item is: 'My manager recognises my potential.' Cronbach’s alpha was .93.

Team cohesiveness was measured using an 8-item scale developed by Dobbins and Zaccaro (1986). An example item is: 'The team which I belong to is a close one.' Cronbach's alpha was .75 . 
Control variables included: age, working part-time/full-time (full-time $=1$ ), contract type (permanent contract=1) and organisation (company $\mathrm{A}=1$ ). These were chosen because overqualification is highly relevant to the ageing of the workforce (Erdogan et al., 2011b), parttime employees tend to experience higher perceptions of overqualification compared to full-time employees (Li, Gervais and Duval, 2006), and temporary workers tend to have lower job satisfaction compared to permanent workers (e.g., Booth, Francesconi and Frank, 2000). The organisation in which the employees worked was controlled for, given the myriad differences in terms of their respective structure, HRM practices, and organisational culture. All analyses were carried out with and without control variables. The results were the same, supporting the robustness of the findings (Becker, 2005).

\section{Results}

\section{Descriptive Statistics}

SPSS (version 22) was used to calculate the descriptive statistics and to test the hypotheses. Table 1 presents the means, standard deviations, and correlations amongst the variables. All correlation coefficients were below .70. Hence, problems associated with multicollinearity are less of a concern (Tabachnick and Fidell, 2007).

Insert Table 1 about here

\section{Hypotheses Testing}

We tested the hypotheses using conditional process analysis. Specifically, we used Hayes' (2013) PROCESS SPSS macro to test the hypotheses. We conducted two separate 
moderated path models, one for leader-member exchange, and another for team cohesiveness. This enabled us to test the independent and moderating roles for each interpersonal relationship simultaneously. Moreover, bootstrapping was used; this is advantageous, especially in smaller samples, and helps to reduce the chances of committing a Type 2 error.

Hayes' procedure simultaneously estimates two models. The first specifies perceived overqualification as the dependent variable, and leader-member exchange (or team cohesiveness) as the predictor variables, whereas the latter specifies job satisfaction as the dependent variable, and overqualification, leader-member exchange (or team cohesiveness), and the cross product of overqualification and leader-member exchange (or team cohesiveness), as predictors. Ninety-five percent bias-corrected bootstrapped confidence intervals were computed to make inferences about significant relationships. The results for each of the moderated path models are presented in Figure 2, and Tables 2 and 3. In particular, the first models in Tables 2 and 3 present the test results for the first set of hypotheses. The second models in Tables 2 and 3 present the test results for the latter two hypotheses. The use of conditional process analysis allowed us to test these models for each interpersonal relationship simultaneously.

Insert Figure 2 about here

Table 2 shows the estimated standardised regression coefficients of the moderated path model, using leader-member exchange as a predictor and moderator. Looking at the first model, leader-member exchange is a negative and significant predictor of perceived overqualification, supporting hypothesis 1 adj. $\left.\mathrm{R}^{2}=.20, F(5,171)=8.47, p<.00\right]$. Turning attention to the second model, the relationship between overqualification and job satisfaction is negative, lending 
support to hypothesis 3. A separate multiple regression analysis with only perceived overqualification and the controls as independent variables $\left[ß=-.31, \mathrm{SE}=.06, p<.001 ; \mathrm{adj} . \mathrm{R}^{2}=\right.$ $.11 ; F(5,171)=5.12, p<.01]$ supported this hypothesis.

The model that predicts job satisfaction in Table 2 also shows that the interaction between perceived overqualification and leader-member exchange was significant $\left[\right.$ adj. $\mathrm{R}^{2}=.31$, $F(7,169)=10.67, p<.00]$. Figure 3 shows the plot with conditional indirect effects of overqualification on job satisfaction estimated for employees who score high (1 standard deviation above the mean) and who score low (1 standard deviation below the mean) on leadermember exchange. The interaction indicates that the slopes are different from one another and the figure depicts a negative relationship between overqualification and job satisfaction, but the slope of the line is less steep for those who have high quality relationships with their leader. Hypothesis 4 is therefore supported.

Insert Table 2 and Figure 3 about here

We also estimated the conditional indirect effects of perceived overqualification on the relationship between leader-member exchange and job satisfaction estimated at two values of leader-member exchange as the moderator (one standard deviation above and below the mean). The indirect effect is significantly positive at low levels of leader-member exchange $(B=.05$, $\mathrm{SE}=.02, p<.05)$; it is not significant at high levels of leader-member exchange $(B=.01, \mathrm{SE}=.01$, $p=$ n.s.). This means that among those who have a high quality relationship with their leader, it is less likely that they perceive that they are overqualified, prompting lower levels of job satisfaction. Thus, the indirect effect of leader-member exchange on job satisfaction through 
perceived overqualification was larger among those who had a poorer relationship with their manager. These results are in line with our theoretical model.

Turning to the results for team cohesiveness as a predictor and moderator, Table 3 shows the estimated standardised regression coefficients of the moderated path model. The results from the first model of this analysis show that team cohesiveness is a negative and significant predictor of perceived overqualification, supporting hypothesis 2 [adj. $\mathrm{R}^{2}=.21, F(5,171)=8.74$, $p<.00]$. The results of the second model revealed that the interaction between perceived overqualification and team cohesiveness was significant [adj. $\left.\mathrm{R}^{2}=.29, F(7,169)=9.65, p<.00\right]$. Figure 4 shows the plot with conditional indirect effects of overqualification on job satisfaction estimated for employees who score high (1 standard deviation above the mean) and who score low (1 standard deviation below the mean) on team cohesiveness. The interaction implies that the slopes are different from one another, and the figure shows a negative relationship between overqualification and job satisfaction, but the slope of the line is less steep for those who have high levels of team cohesiveness. Hypothesis 5 is therefore supported.

Insert Table 3 and Figure 4 about here

We computed the conditional indirect effects of perceived overqualification on the relationship between team cohesiveness and job satisfaction estimated at two values of team cohesiveness as a moderator (one standard deviation above and below the mean). The indirect effect is significant and positive at low levels of team cohesiveness ( $B=.08, \mathrm{SE}=.04, p<.05)$; it is not significant at high levels of team cohesiveness $(B=.02, \mathrm{SE}=.02, p=$ n.s. $)$. These results are in line with our theoretical model; the indirect effect of team cohesiveness on job satisfaction 
through perceived overqualification was larger among those who belonged to less cohesive teams.

We carried out two post-hoc tests in order to explore the data further. First, we tested the proposition that overqualified employees' job satisfaction is highest when they have higher quality relationships with both their leader and team. Results of the regression analyses showed that the three-way interaction was not significant. This suggests that leader-member exchange and team cohesiveness independently moderate the relationship between perceived overqualification and job satisfaction; they do not jointly influence this relationship.

Second, we regressed job satisfaction on both leader-member exchange and team cohesiveness, along with the control variables, to determine their relative strength in their association with job satisfaction. The results showed that although the coefficients representing both team cohesiveness $(~(B=-.25, \mathrm{SE}=.13, p<.05)$ and leader-member exchange $(ß=-.14, \mathrm{SE}=.09$, $p=.11)$ were in the expected negative direction, only the former was statistically significant [adj. $\left.\mathrm{R}^{2}=.22, F(6,171)=7.77, p<.00\right]$.

\section{Discussion}

Our results contribute to overqualification and HRM theories in a number of ways. First, we contribute to overqualification theory by identifying two antecedents of perceptions of overqualification. Although theoretical models and some empirical evidence has identified factors that are associated with perceived overqualification (e.g., Feldman, 1996; McKee-Ryan and Harvey, 2011), this is the first study, to our knowledge to examine proximal, work-related factors that have the potential to lessen perceptions of overqualification. Our finding that high quality relationships with one's leader and team are associated with lower levels of perceived 
overqualification is important, as it expands our theoretical understanding of the antecedents of perceived overqualification, and it also may guide organisations in managing these perceptions among employees.

Although it appears that both interpersonal relationship partners have the potential to influence perceptions of overqualification, when overqualification was regressed on both variables, only team cohesiveness remained statistically significant. This highlights the important role of overqualified employees' team members in influencing their responses to their perceptions of overqualification. This finding resonates with research that has examined how individuals respond to their overqualified status based on the extent to which others in their team are overqualified (Alfes, 2013; Hu et al., 2015).

The present study also contributes to overqualification theory via our moderation results. Empirical evidence on the buffering effect of workplace phenomena on the relationship between perceived overqualification and its reported negative outcomes is sparse (Erdogan et al., 2011b). Although prior research has established that factors related to employees' work tasks are important in shielding against the negative ramifications of perceived overqualification (Erdogan and Bauer, 2009), the present study found that interpersonal relationships that employees hold at work likewise reduce the negative effect of perceived overqualification on job satisfaction. This study therefore enhances overqualification theory by identifying conditions under which the relationship between perceived overqualification and its outcome is attenuated (Whetten, 1989). In doing so, we show how relative deprivation theory and social exchange theory can be integrated and leveraged to understand how interpersonal relationships at work mitigate the negative relationship between perceived overqualification and job satisfaction by emphasising 
how tangible and intangible resources reduce overqualified employees' feelings of relative deprivation.

It is also noteworthy that we tested our hypotheses using conditional process analysis (Hayes, 2013) and found that interpersonal relationships at work serve (at least) two roles: they acted as both antecedents of overqualification, and also as moderators of the relationship between overqualification and job satisfaction. That both roles were statistically significant within the same test provides a nuanced account of the impact of social relationships on those who are overqualified.

Although our theory building emphasised the importance of resources, we did not examine the particular tangible or intangible resources that are principal in influencing overqualified employees' job attitudes. Future research should therefore explore which resources are most relevant in reducing feelings of relative deprivation. It is plausible that the provision of challenging assignments is particularly helpful in influencing overqualified employees' job satisfaction for two reasons. First, challenging assignments may enable overqualified employees to carry out tasks that match the skills and knowledge they have acquired. Second, challenging assignments are an important development tool which may facilitate overqualified employees' transition from their current job to one in which they feel adequately qualified (McCauley, Eastman and Ohlott, 1995).

Our research findings may also be of interest in light of those found by Bal, Chiaburu and Jansen (2010), who found that social exchange relationships intensified the negative relationship between psychological contract breach and the outcomes in Bal et al.'s study. Juxtaposed against the present findings, we are left with the nagging question of why social exchange relationships reduced the negative effect of perceived overqualification on job satisfaction in the present study, 
but it intensified the negative relationship between psychological contract breach and in-role performance and citizenship behaviours in the study conducted by Bal et al. (2010). A potential explanation is that in Bal et al.'s study, employees' psychological contract breach occurred because of an unfulfilled promise, whereas in the present study, employees likely knew that they were overqualified for their jobs when they were hired, and therefore did not perceive a violated promise. Future research designed to shed light on these different findings is welcome.

The limitations inherent in the present study may also open avenues for future research. For instance, the study's cross-sectional design limits our ability to assert causality in the proposed relationships. Although the hypothesised relationships are grounded in strong theoretical underpinnings and are in line with previous research on perceived overqualification, we cannot rule out the possibility of reverse-causality. Additionally, our data was collected from one source, raising concerns regarding common method variance. However, our latter two hypotheses and findings are related to moderating relationships (i.e. interactions), and common method variance does not explain the findings of a significant interaction (McClelland and Judd, 1993; Siemsen, Roth and Oliveira, 2010). Moreover, we employed procedural remedies as described by Podsakoff et al. (2003) for reducing common method bias. For example, we ensured survey anonymity through de-identified surveys and anonymous returns, separated predictors and criteria on the survey, and ensured scale item quality (e.g., items had familiar terms in the Dutch context).

We also conducted a series of confirmatory factor analyses in AMOS (version 22) to assess the extent to which common method bias was present in our data, as well as to determine the distinctiveness of the constructs. The full measurement model, in which all items for the four scales loaded onto their respective factors, fit the data well (Hair et al., 2009). We also compared 
the full measurement model to four alternative nested models; the results showed that the fit of the alternative models was significantly worse compared to the full measurement model (all at $p<.001)$. Finally, we introduced an unmeasured latent methods factor to our original measurement model allowing all items to load on to their theoretical constructs, as well as on to the latent methods factor. The results, available from the first author, indicated that common method bias did not unduly influence the results. Notwithstanding, future research should examine the hypothesised model using a longitudinal design and other-rated measures.

Future research should also examine our hypothesised model in different organisations using a larger sample. Our sample is admittedly small $(n=183)$ and included two organisations in the Netherlands. The results may differ across industries or national contexts.

A further limitation relates to our measure of overqualification. Employees’ perceptions of overqualification do not necessarily reflect an accurate assessment of reality; employees might believe that they are overqualified even though they might be adequately qualified for their jobs. Arguably, a perceptual measure is appropriate in the present study, as it is employees' perception of their employment situation that most strongly influences how they feel about their jobs (Maynard et al., 2006; Erdogan et al., 2011a). Nevertheless, we encourage future research to include both objective and subjective measures of overqualification in their analyses.

Moreover, it is important to note that the beta-coefficients associated with the interaction terms are relatively small, and although the relationship between overqualification and job satisfaction is weakened for those with higher quality interpersonal relationships with others, it was not completely reduced. Yet, given the complicated nature of identifying moderating relationships in field studies, even $1 \%$ of incremental variance explained by an interaction is a meaningful finding (Evans, 1985; McClelland and Judd, 1993). In our study, the interaction term 
for leader-member exchange and team cohesiveness explained $2 \%$ of incremental variance on job satisfaction, respectively, demonstrating that the moderating effects, albeit small, are meaningful. However, the provision of high quality interpersonal relationships at work does not guarantee that overqualified employees will become fully satisfied. Instead, we can conclude that there is room for future research to identify additional ways to weaken the negative relationship between perceived overqualification and job satisfaction.

A final limitation relates to the measure of leader-member exchange. Although our interest was in employees' perception of the quality of the relationships they have with their leaders, scholars have argued that leader-member exchange should be measured at the dyadic level (Schriesheim, Castro, Zhou and Yammarino, 2001). Exploring the dyadic relationship between supervisors and their employees in a team can, for example, inform the extent to which there is variability in the relationships between the manager and each team member within the team. Future research should examine the extent to which overqualified employees belong to their leader's in-group (as measured by the relative dyadic exchange quality), and the extent to which this results in the provision of increased discretion in how to carry out their work.

\section{Practical Implications}

The results of the present study confirm that employees who believe that they are overqualified for their jobs report greater job dissatisfaction. However, the results do not necessarily imply that HRM professionals should refrain from hiring overqualified employees. This is because they can reduce the negative effects of overqualification through the provision of high quality leadership and the facilitation of cohesive teams. This is an especially important finding for organisations, since research has established that overqualified employees tend to 
perform at a higher level than their adequately qualified counterparts (e.g., Fine and Nevo, 2008). Hence, HRM professionals can capitalise on the higher performance of overqualified employees, and ensure that their job attitudes are positive if they put conditions in place where employees have high quality relationships with their leader and are positioned in cohesive teams. HRM departments should invest in ensuring the development and maintenance of high quality relationships between managers and employees. To facilitate high quality relationships, managers should regularly communicate how employees contribute to the success of the broader organisation. Moreover, they should clearly communicate work expectations, while at the same time ensuring that employees' knowledge, skills and abilities are used at work, decreasing feelings of deprivation. Leaders should also ensure that employees feel valued for their contributions by, for example, celebrating individual and group successes. HRM departments can also sponsor formal training programmes for leaders which focus on leading by example, employee participation, and delegation to increase involvement and self-esteem among overqualified employees (Scandura and Graen, 1984).

In addition, HRM departments should invest in raising levels of team cohesiveness. To do so, teams should be tasked with relatively complex work and be provided with sufficient autonomy to make group-based decisions (Man and Lam, 2003). Doing so may assist those who perceive that they are overqualified to feel that their talents are utilised at work. Managers can attempt to heighten group cohesion by increasing team members' interpersonal attraction to one another by organising social events amongst team members (e.g., collective coffee breaks; bowling socials). Ensuring that each team member is integrated in the team through regular interaction may increase the feeling of being valued. 


\section{Conclusion}

HRM practitioners often refrain from hiring job candidates who are overqualified for fear that they may be dissatisfied and ultimately leave the organisation. The results of our study show that this conclusion may be incomplete as it fails to take into consideration the possibility that factors in the work environment, such as high leader-member exchange and team cohesiveness, may not only reduce the extent to which employees perceive that they are overqualified, but they may also weaken the negative effect of perceived overqualified on job satisfaction. Hence, the assumption that overqualified employees suffer from lower levels of job satisfaction is true only part of the time, and cultivating high quality interpersonal relationships at work is an effective way to reduce perceptions of overqualification, as well as the potential negative ramifications of it. 


\section{References}

Alfes, K. (2013). 'Perceived overqualification and performance. The role of the peer group'. Zeitschrift für Personalforschung, 27: 4, 314-330.

Armeli, S., Eisenberger, R., Fasolo, P. and Lynch, P. (1998). 'Perceived Organizational Support and Police Performance: The Moderating Influence of Socioemotional Needs'. Journal of Applied Psychology, 83: 2, 288-297.

Aryee, S. and Zhen Xiong, C. (2006). 'Leader-member exchange in a Chinese context: Antecedents, the mediating role of psychological empowerment and outcomes'. Journal of Business Research, 59: 7, 793-801.

Bal, P.M., Chiaburu, D.S. and Jansen, P.G.W. (2010). 'Psychological contract breach and work performance: Is social exchange a buffer or an intensifier?'. Journal of Managerial Psychology, 25: 3, 252-273.

Becker, T.E. (2005). 'Potential problems in the statistical control of variables in organizational research: A qualitative analysis with recommendations'. Organizational Research Methods, 8, 274-289.

Booth, A.L., Francesconi, M. and Frank, J. (2000). 'Temporary jobs: Stepping stones or dead ends? IZA Discussion Paper Series No. 205.'

Brislin, R.W., Lonner, W.J. and Thorndike, R.M. (1973). Cross-cultural research methods, New York: Wiley.

Carson, J.B., Tesluk, P.E. and Marrone, J.A. (2007). 'Shared Leadership in Teams: An Investigation of Antecedent Conditions and Performance'. Academy of Management Journal, 50: $5,1217-1234$.

Cartwright, D. (1968). 'The nature of group cohesiveness', in D. Cartwright and A. Zander (eds.), Group dynamics: Research and theory, (3 ed.), New York: Harper \& Row, pp. 91-109.

Colquitt, J.A. and Zapata-Phelan, C.P. (2007). 'Trends in Theory Building and Theory Testing. A five-decade study of the Academy of Management Journal'. Academy of Management Journal, 50: $6,1281-1303$.

Crosby, F. (1976). 'A model of egoistical relative deprivation'. Psychological Review, 83: 2, 85113.

Dobbins, G.H. and Zaccaro, S.J. (1986). 'The Effects of Group Cohesion and Leader Behavior on Subordinate Satisfaction'. Group \& Organization Management, 11: 3, 203-219.

Edwards, P., Sengupta, S. and Tsai, C.-J. (2009). 'Managing low-skill workers: a study of small UK food manufacturing firms'. Human Resource Management Journal, 19: 1, 40-58. 
Erdogan, B. and Bauer, T.N. (2009). 'Perceived Overqualification and Its Outcomes: The Moderating Role of Empowerment'. Journal of Applied Psychology, 94: 2, 557-565.

Erdogan, B., Bauer, T.N., Peiro, J.M. and Truxillo, D.M. (2011a). 'Overqualification Theory, Research, and Practice: Things That Matter'. Industrial and Organizational Psychology, 4: 2, 260-267.

Erdogan, B., Bauer, T.N., Peiro, J.M. and Truxillo, D.M. (2011b). 'Overqualified Employees: Making the Best of a Potentially Bad Situation for Individuals and Organizations'. Industrial and Organizational Psychology, 4: 2, 215-232.

Evans, M.G. (1985). 'A Monte Carlo study of the effects of correlated method variance in moderated multiple regression analysis'. Organizational Behavior and Human Decision Processes, 36: 3, 305-323.

Faragher, E.B., Cass, M. and Cooper, C.L. (2005). 'The relationship between job satisfaction and health: a meta-analysis'. Occupational and Environmental Medicine, 62: 2, 105-112.

Feldman, D.C. (1996). 'The nature, antecedents and consequences of underemployment'. Journal of Management, 22: 3, 385-407.

Feldman, D.C., Leana, C.R. and Bolino, M.C. (2002). 'Underemployment and relative deprivation among re-employed executives'. Journal of Occupational and Organizational Psychology, 75: 4, 453-471.

Fenlason, K.J. and Beehr, T.A. (1994). 'Social support and occupational stress: Effects of talking to others'. Journal of Organizational Behavior, 15: 2, 157-175.

Fine, S. and Nevo, B. (2008). 'Too smart for their own good? A study of perceived cognitive overqualification in the workforce'. The International Journal of Human Resource Management, 19: 2, 346-355.

Gerstner, C.R. and Day, D.V. (1997). 'Meta-Analytic Review of Leader-Member Exchange Theory: Correlates and Construct Issues'. Journal of Applied Psychology, 82: 6, 827-844.

Graen, G.B. and Uhl-Bien, M. (1995). 'Relationship-based approach to leadership: Development of leader-member exchange (LMX) theory of leadership over 25 years: Applying a multi-level multi-domain perspective'. The Leadership Quarterly, 6: 2, 219-247.

Green, A. (2013). Why Employers Don't Want to Hire Overqualified Candidates. US News and World Report. Retrieved on: December 15, 2014 at: http://money.usnews.com/money/blogs/outside-voices-careers/2013/07/31/why-employers-dontwant-to-hire-overqualified-candidates.

Groot, W. and Maassen van den Brink, H. (2000). 'Overeducation in the labor market: a metaanalysis'. Economics of Education Review, 19: 2, 149-158. 
Grugulis, I. (2003). 'Putting skills to work: learning and employment at the start of the century'. Human Resource Management Journal, 13: 2, 3-12.

Hair, J.F., Black, W.C., Babin, B.J. and Anderson, R.E. (2009). Multivariate Data Analysis, New Jersey: Pearson Prentice Hall.

Hausknecht, J.P., Trevor, C.O. and Howard, M.J. (2009). 'Unit-Level Voluntary Turnover Rates and Customer Service Quality: Implications of Group Cohesiveness, Newcomer Concentration, and Size'. Journal of Applied Psychology, 94: 4, 1068-1075.

Hayes, A.F. (2013). An introduction to mediation, moderation, and conditional process analysis: A regression-based approach, New York.

Hu, J., Erdogan, B., Bauer, T.N., Jiang, K., Liu, S. and Li, Y. (2015). 'There are lots of big fish in this pond: The role of peer overqualification on task significance, perceived fit, and performance for overqualified employees'. Journal of Applied Psychology, 100: 4, 1228-1238.

Hüffmeier, J. and Hertel, G. (2011). 'Many cheers make light the work: how social support triggers process gains in teams'. Journal of Managerial Psychology, 26: 3, 185-204.

Johnson, G.J. and Johnson, W.R. (1997). 'Perceived Overqualification, Emotional Support, and Health'. Journal of Applied Social Psychology, 27: 21, 1906-1918.

Judge, T.A., Bono, J.E., Thoresen, C.J. and Patton, G.K. (2001). 'The Job Satisfaction-Job Performance Relationship: A Qualitative and Quantitative Review'. Psychological Bulletin, 127: 3, 376-407.

Kidwell, R.E., Mossholder, K.W. and Bennett, N. (1997). 'Cohesiveness and Organizational Citizenship Behavior: A Multilevel Analysis Using Work Groups and Individuals'. Journal of Management, 23: 6, 775.

Kraimer, M.L., Shaffer, M.A. and Bolino, M.C. (2009). 'The influence of expatriate and repatriate experiences on career advancement and repatriate retention'. Human Resource Management, 48: 1, 27-47.

Lee, C.H. (2005). 'A study of underemployment among self-initiated expatriates'. Journal of World Business, 40: 2, 172-187.

Lewin, K. (1943). 'Defining the 'field at a given time". Psychological Review, 50: 3, 290-310.

Li, C., Gervais, G. and Duval, A. (2006). The dynamics of overqualification: Canada's underemployed university graduates, Ottawa, Canada: Minister of Industry.

Lim, V.K.G. (1996). 'Job Insecurity and Its Outcomes: Moderating Effects of Work-Based and Nonwork-Based Social Support'. Human Relations, 49: 2, 171-194.

Locke, E.A. (1976). 'The nature and causes of job satisfaction', in M.D. Dunnette (ed.), Handbook of industrial and organizational psychology, Chicago: Rand McNally, pp. 1297-1349. 
Man, D.C. and Lam, S.S.K. (2003). 'The effects of job complexity and autonomy on cohesiveness in collectivistic and individualistic work groups: a cross-cultural analysis'. Journal of Organizational Behavior, 24: 8, 979-1001.

Maynard, D.C., Joseph, T.A. and Maynard, A.M. (2006). 'Underemployment, job attitudes, and turnover intentions'. Journal of Organizational Behavior, 27: 4, 509-536.

McCauley, C.D., Eastman, L.J. and Ohlott, P.J. (1995). 'Linking management selection and development through stretch assignments'. Human Resource Management, 34: 1, 93-115.

McClelland, G.H. and Judd, C.M. (1993). 'Statistical difficulties of detecting interactions and moderator effects'. Psychological Bulletin, 114: 2, 376-390.

McKee-Ryan, F.M. and Harvey, J. (2011). "“I Have a Job, But . ..”: A Review of Underemployment'. Journal of Management, 37: 4, 962-996.

Podsakoff, P.M., MacKenzie, S.B., Jeong-Yeon, L. and Podsakoff, N.P. (2003). 'Common Method Biases in Behavioral Research: A Critical Review of the Literature and Recommended Remedies'. Journal of Applied Psychology, 88: 5, 879-903.

Pouliakas, K. (2013). 'The skill mismatch challenge in Europe. Employment and Social Developments in Europe 2012', Publications Office of the European Union.

Quintini, G. (2011). 'Over-qualified or under-skilled. A review of existing literature. OECD Social, employment and Migration Working Papers No. 121,' Paris: Organisation for Economic Cooperation and Development.

Ritz, A., Shantz, A., Alfes, K. and Arshoff, A.S. (2012). 'Who Needs Leaders the Most? The Interactive Effect of Leadership and Core Self-Evaluations on Commitment to Change in the Public Sector'. International Public Management Journal, 15: 2, 160-185.

Scandura, T.A. and Graen, G.B. (1984). 'Moderating effects of initial leader-member exchange status on the effects of a leadership intervention'. Journal of Applied Psychology, 69: 3, 428-436.

Schermerhorn, J.R., Hunt, J.G. and Osborn, R.N. (2002). Organizational Behavior, New York: Wiley.

Schriesheim, C.A., Castro, S.L., Zhou, X. and Yammarino, F.J. (2001). 'The folly of theorizing "A" but testing "B": A selective level-of-analysis review of the field and a detailed LeaderMember Exchange illustration'. The Leadership Quarterly, 12: 4, 515-551.

Seibert, S., Sparrowe, R.T. and Liden, R.C. (2003). 'A group exchange structure approach to leadership in groups', in C. Pearce and J. Conger (eds.), Shared Leadership: Reframing the 'Hows' and 'Whys' of Leadership, Newbury Park, CA: Sage, pp. 173-192.

Shore, L.M., Bommer, W.H., Rao, A.N. and Seo, J. (2009). 'Social and economic exchange in the employee-organization relationship: the moderating role of reciprocation wariness'. Journal of Managerial Psychology, 24: 8, 701-721. 
Shore, L.M., Tetrick, L.E., Lynch, P. and Barksdale, K. (2006). 'Social and Economic Exchange: Construct Development and Validation'. Journal of Applied Social Psychology, 36: 4, 837-867.

Siemsen, E., Roth, A. and Oliveira, P. (2010). 'Common method bias in regression models with linear, quadratic, and interaction effects'. Organizational Research Methods, 13: 3, 456-476.

Sullivan, J. (2014). Refusing to Hire Overqualified Candidates. HR Certification Institute. Retrieved on: December 1, 2014 at: http://www.ere.net/2014/08/25/refusing-to-hireoverqualified-candidates-a-myth-that-can-hurt-your-firm/.

Tabachnick, B.G. and Fidell, L.S. (2007). Using Multivariate Statistics, Boston: Pearson.

Takeuchi, R., Chen, G. and Lepak, D.P. (2009). 'Through the looking glass of a social system. Cross-level effects of high-performance work systems on employees' attitudes'. Personnel Psychology, 62: 1, 1-29.

Thatcher, S.M.B. and Patel, P.C. (2011). 'Demographic Faultlines: A Meta-Analysis of the Literature'. Journal of Applied Psychology, 96: 6, 1119-1139.

Tummers, L.G. and Knies, E. (2013). 'Leadership and Meaningful Work in the Public Sector'. Public Administration Review, 73: 6, 859-868.

Vaisey, S. (2006). 'Education and its Discontents: Overqualification in America, 1972-2002'. Social Forces, 85: 2, 835-864.

Van Dick, R., Tissington, P.A. and Hertel, G. (2009). 'Do many hands make light work?: How to overcome social loafing and gain motivation in work teams'. European Business Review, 21: 3, 233-245.

Van Dyne, L., Cummings, L.L. and Parks, J.M. (1995). 'Extra-role behaviors: In pursuit of construct and definitional clarity (a bridge over mudded waters)', in L.L. Cummings and B.M. Staw (eds.), Research in Organizational Behavior, Greenwich, JT: JAI Press, pp. 215-285.

Vecchio, R.P. (1997). 'Are you in or out with your boss?', in R.P. Vecchio (ed.), Leadership: Understanding the dynamics of power and influence in organizations, Notre Dame: University of Notre Dame Press, pp. 274-277.

Whetten, D.A. (1989). 'What Constitutes a Theoretical Contribution?'. Academy of Management Review, 14: 4, 490-495.

Zalesny, M.D. and Ford, J.K. (1990). 'Extending the social information processing perspective: New links to attitudes, behaviors, and perceptions'. Organizational Behavior and Human Decision Processes, 47: 2, 205-246. 
Tables and Figures

Table 1: Descriptive Statistics

\begin{tabular}{|c|c|c|c|c|c|c|c|c|c|}
\hline & $\mathrm{M}$ & SD & 1. & 2. & 3. & 4. & 5. & 6. & 7. \\
\hline 1. Age & 32.41 & 8.57 & & & & & & & \\
\hline 2. Full-time & .64 & .48 & .14 & & & & & & \\
\hline 3. Organisation A & .26 & .44 & $.29 * *$ & $-.21 * *$ & & & & & \\
\hline 4. Permanent contract & .69 & .46 & $.43 * *$ & .05 & $.20 * *$ & & & & \\
\hline 5. Perceived overqualification & 3.90 & 1.34 & $-.27 * *$ & .10 & -.05 & $-.35^{* *}$ & & & \\
\hline 6. Job satisfaction & 6.07 & .98 & $.16^{*}$ & -.13 & .10 & .13 & $-.34 * *$ & & \\
\hline 7. Leader-member exchange & 5.53 & 1.17 & .03 & -.08 & .03 & .09 & $-.20 * *$ & $.45^{* *}$ & \\
\hline 8. Team cohesiveness & 5.99 & .81 & .01 & $-.20 * *$ & -.04 & $.15^{*}$ & $-.25 * *$ & $.42 * *$ & $.39 * *$ \\
\hline
\end{tabular}


Table 2: Moderated Path Model of Leader-Member Exchange (LMX), Perceived Overqualification and Job Satisfaction

(1) Dependent Variable $=$ Perceived Overqualification

\begin{tabular}{lcc}
\hline Independent Variables & $\boldsymbol{\beta}($ standard error) & Lower Cl, Upper CI \\
\hline Age & $-.03(.01)^{*}$ & $-.06,-.01$ \\
Full-time & $-.42(.20)^{*}$ & $-.82,-.03$ \\
Organisation & $.26(.23)$ & $-.19, .70$ \\
Permanent & $-.80(.22)^{* *}$ & $-1.24,-.36$ \\
LMX & $-.20(.08)^{*}$ & $-.35,-.04$
\end{tabular}

(2) Dependent Variable = Job Satisfaction

\begin{tabular}{lll}
\hline Independent Variables $\quad$ B(standard error) & Lower Cl, Upper CI
\end{tabular}

\begin{tabular}{lcc}
\hline Age & $.01(.01)$ & $-.01, .03$ \\
Full-time & $.16(.14)$ & $-.11, .43$ \\
Organisation & $.13(.15)$ & $-.17, .43$ \\
Permanent & $-.10(.16)$ & $-.41, .21$ \\
LMX & $.04(.17)$ & $-.30, .37$ \\
Overqualification & $-.59(.23)^{*}$ & $-1.04,-.13$ \\
LMX x Overqualification & $.08(.04)^{*}$ & $.01-.16$
\end{tabular}

Notes: $p^{*<.05} \mathrm{p}^{* *<.01} ; \mathrm{CI}=95 \%$ bias corrected bootstrapped confidence intervals 
Table 3: Moderated Path Model of Team Cohesiveness, Perceived Overqualification and Job Satisfaction

(1) Dependent Variable $=$ Perceived Overqualification

\begin{tabular}{lcc}
\hline Independent Variables & $\boldsymbol{\beta}$ (standard error) & Lower Cl, Upper CI \\
\hline Age & $-.03(.01)^{*}$ & $-.06,-.01$ \\
Full-time & $-.35(.20)$ & $-.75, .05$ \\
Organisation & $.20(.23)$ & $-.25, .64$ \\
Permanent & $-.75(.22)^{* *}$ & $-1.18,-.30$ \\
Team Cohesiveness & $-.32(.11)^{* *}$ & $-.55,-.09$
\end{tabular}

(2) Dependent Variable $=$ Job Satisfaction

\begin{tabular}{lcc}
\hline Independent Variables & $\boldsymbol{\beta}($ standard error) & Lower Cl, Upper CI \\
\hline Age & $.01(.01)$ & $-.01, .03$ \\
Full-time & $.06(.14)$ & $-.22, .34$ \\
Organisation & $.22(.16)$ & $-.09, .52$ \\
Permanent & $-.20(.16)$ & $-.52, .12$ \\
Team Cohesiveness & $-.01(.24)$ & $-.48, .46$ \\
Overqualification & $-.85(.33)^{*}$ & $-1.51,-.19$ \\
Team Cohesiveness $\mathrm{x}$ & $.12(.06)^{*}$ & $.01, .23$ \\
Overqualification & & \\
\hline
\end{tabular}

Notes: $p^{*<.05} \mathrm{p}^{* *<.01} ; \mathrm{CI}=95 \%$ bias corrected bootstrapped confidence intervals 
Figure 1: Conceptual Model

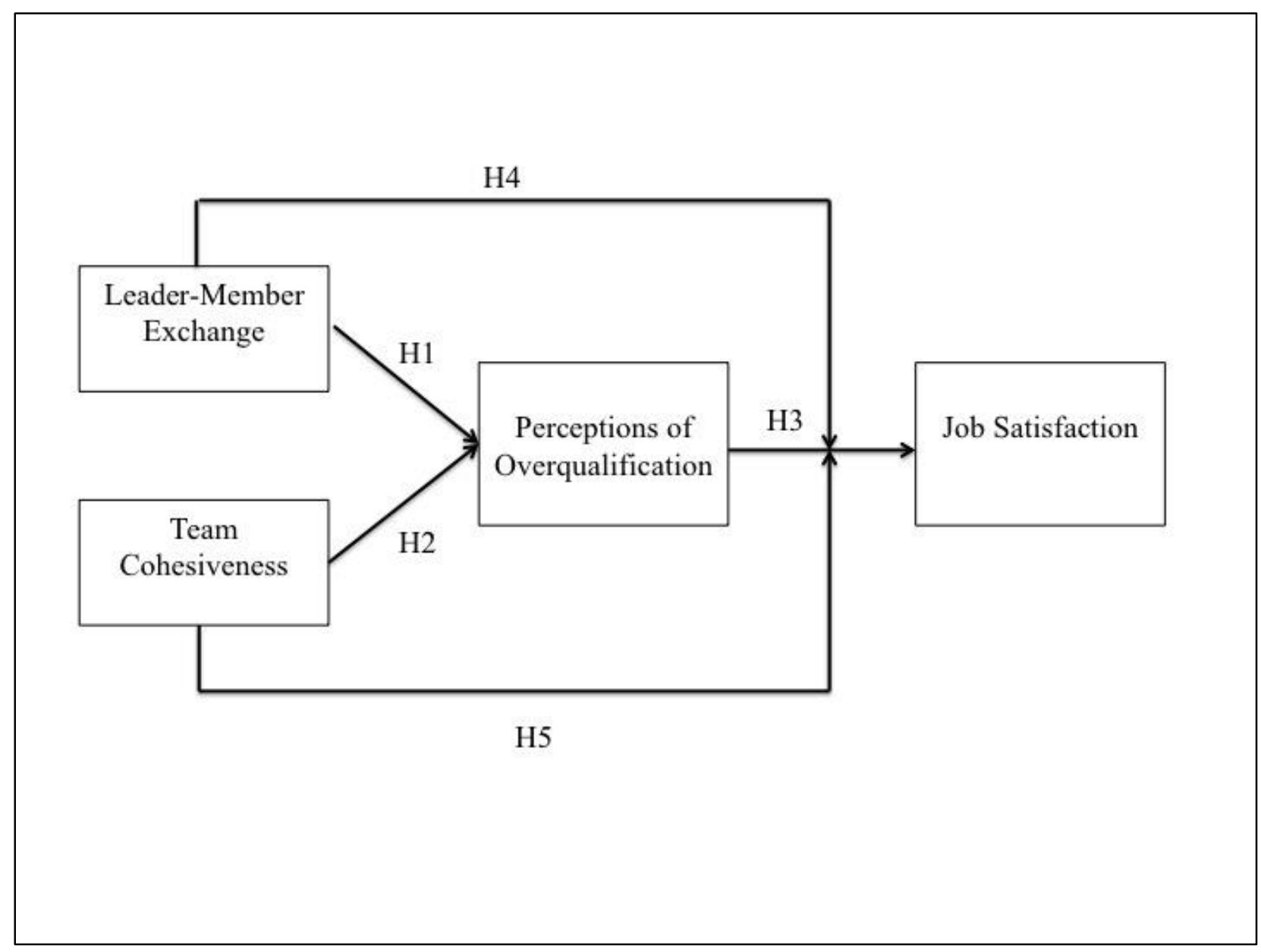


Figure 2: Empirical Model

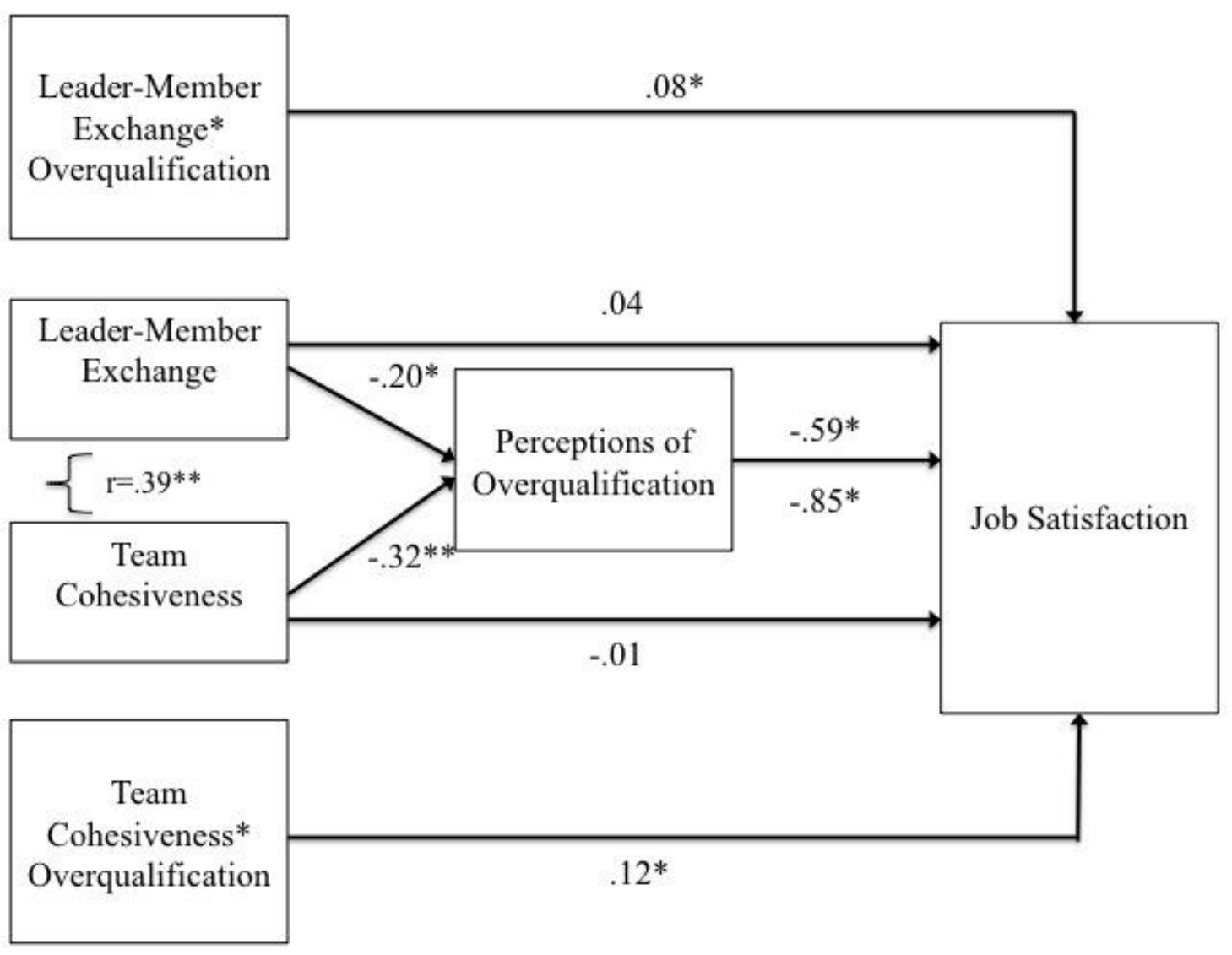


Figure 3: The Effect of Leader-Member Exchange (LMX) on the Relationship between Perceptions of Overqualification and Job Satisfaction

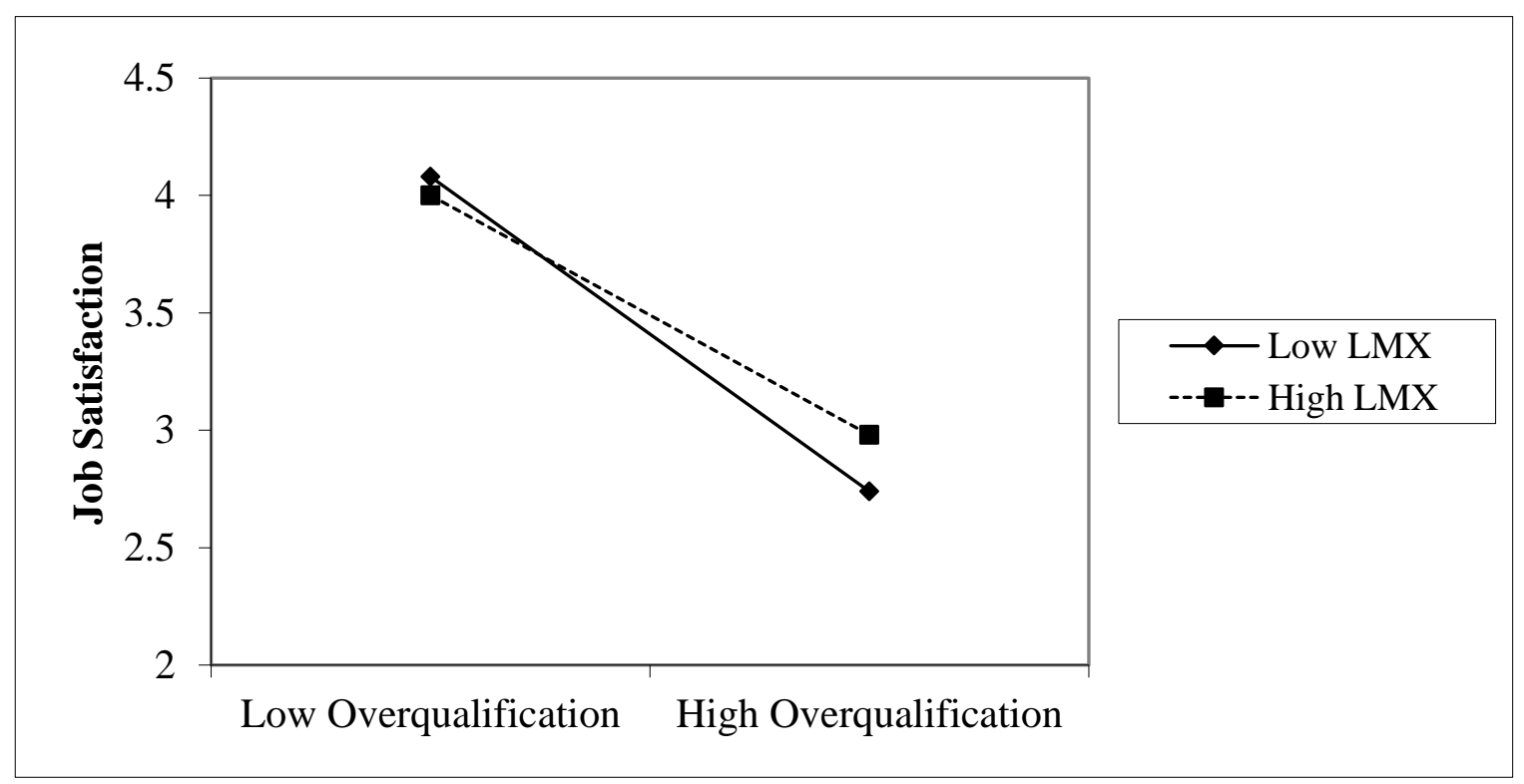


Figure 4: The Effect of Team Cohesiveness on the Relationship between Perceptions of Overqualification and Job Satisfaction

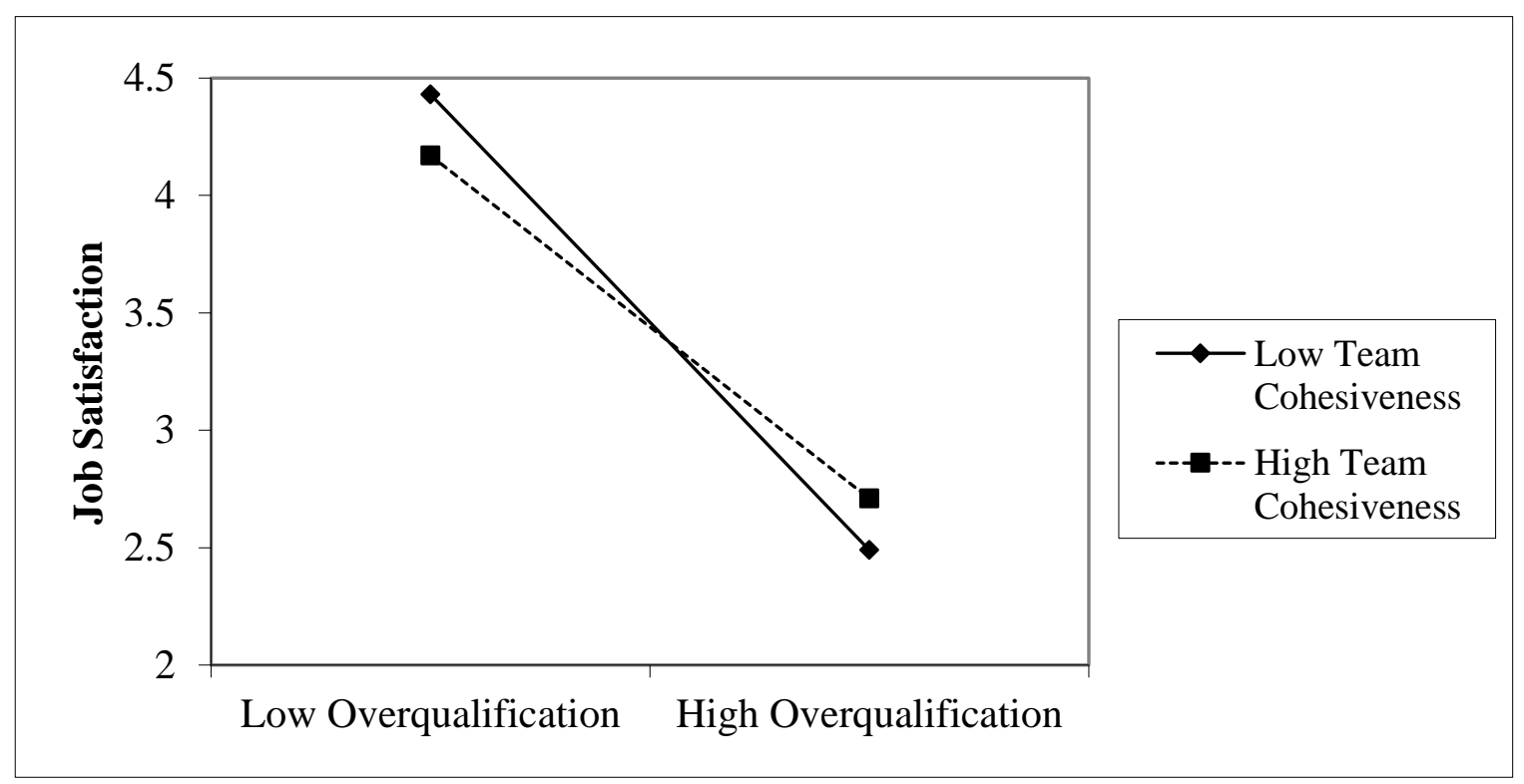

